DOI: $10.14451 / 2.131 .24$

\title{
ОСОБЕННОСТИ ДЕЯТЕЛЬНОСТИ ТОРГОВО-ПРОМЫШЛЕННОЙ ПАЛАТЫ РОССИЙСКОЙ ФЕДЕРАЦИИ В СФЕРЕ ИНТЕЛЛЕКТУАЛЬНОЙ СОБСТВЕННОСТИ
}

\author{
(c) 2019 Барковская Людмила Евгеньевна \\ соискатель \\ Российская государственная академия интеллектуальной собственности, Россия, Москва
}

В настоящей статье на примере деятельности совета Торгово-промышленной палаты Российской Федерации по интеллектуальной собственности автор отмечает роль и значение деятельности различных ассоциаций и союзов в сфере интеллектуальной собственности. Автор отмечает, что пример совета Торгово-промышленной палаты РФ по интеллектуальной собственности подтверждает необходимость законодательного закрепления роли и полномочий ассоциаций и союзов в сфере интеллектуальной собственности.

Ключевые слова: интеллектуальная собственность, Торгово-промышленная палата Российской Федерации, законопроект.

Для построения инновационной экономики в России необходимо проведение такой социально-экономической политики, которая создавала бы благоприятные условия для творческой деятельности и последующей коммерциализации ее результатов. В этом вопросе особую роль играют различные ассоциации и союзы, такие как Союз писателей России, Союз композиторов России, Всероссийское общество изобретателей и рационализаторов, Торговопромышленная палата Российской Федерации и другие. Они консолидируют интересы авторов и правообладателей и представляют их во взаимоотношениях с государственной властью и обществом, тем самым влияя на проводимую государственную политику в области науки, культуры, образования и других сферах, в которых интеллектуальная собственность имеет важное значение.

Вместе с тем, как ранее отмечал автор [8], несмотря на столь значимую роль, которую играют различные ассоциации и союзы в развитии системы интеллектуальной собственности в России, их функции и полномочия никак не закреплены и не отражены в части 4 Гражданского кодекса Российской Федерации [2] (далее - ГК РФ). На наш взгляд, это является серьезной проблемой, так как не позволяет данным организациям в полной мере реализовать свой организационный и юридический потенциал в данном вопросе.

Для того, чтобы разобраться с тем, какое влияние может оказывать на сферу интеллекту- альной собственности деятельности различных ассоциаций и союзов, и каким образом можно зафиксировать их функцию и роль, автор предлагает обратиться к правовым основаниям и опыту деятельности Торгово-промышленной палаты Российской Федерации (далее - ТПП РФ) и совета ТПП РФ по интеллектуальной собственности.

Общепризнанно, что деятельность ТПП РФ имеет огромное значение для развития экономики и бизнеса в России. В том числе деятельность ТПП РФ затрагивает и сферу интеллектуальной собственности. Такое значение деятельность торгово-промышленных палат приобрела благодаря особенностям их правового статуса. В первую очередь необходимо отметить, что деятельность торгово-промышленных палат регулируется профильным законом - законом № 5340-1 от 7 июля 1993 года «О торговопромышленных палатах в Российской Федерации» [3] (далее-закон о торгово-промышленных палатах).

В первую очередь необходимо отметить, что в соответствии с п. 1 ст. 1 Закона о торгово-промышленных палатах торговопромышленная палата является негосударственной некоммерческой организацией, созданной в организационно-правовой форме союза. Таким образом, торгово-промышленные палаты являются негосударственными организациями, однако, п. 1 ст. 4 Закона устанавливает, что государственные органы и органы местного самоуправления оказывают торгово-промышленным 
палатам содействие в выполнении ими своих уставных задач, принимают меры по обеспечению помещениями торгово-промышленных палат. Что это означает? Как некоммерческая организация ТПП РФ по отношению к государству является частным лицом. Вместе с тем закон предоставляет в данном случае таким частным лицам, как торгово-промышленные палаты, преимущество в виде государственной поддержки и содействия.

Вместе с тем, деятельность каких-либо других ассоциаций и союзов не имеет такой законодательно закрепленной государственной поддержки. Само собой, в таких условиях деятельность системы торгово-промышленных палат будет иметь особую значимость для развития экономики страны.

Частные лица и организации не могут вмешиваться в деятельность государственных органов, в том числе в деятельность по подготовке проектов законов и иных нормативных правовых актов. А если какая-то организация и подготовит какой-либо законопроект, то он будет являться ничем иным, кроме как частным мнением и не более того. И государственные органы не обязаны прислушиваться к такому мнению, равно как и привлекать какие-либо организации к подготовке проектов законов. А вот с торгово-промышленными палатами ситуация обстоит совсем иначе. Так пп. а) п. 1 ст. 12 Закона о торгово-промышленных палатах устанавливает, что торгово-промышленные палаты имеют право участвовать в подготовке проектов законов и иных нормативных правовых актов, затрагивающих интересы предпринимателей, в форме, определяемой органами государственной власти или органами местного самоуправления. Порядок реализации данного права конкретизирован в ст. 16 Закона.

Конечно, ТПП РФ в соответствии с п. 1 ст. 104 Конституции Российской Федерации [1] не относится к субъектам законодательной инициативы, однако участие в подготовке законопроектов и не требует этого от лиц, которые принимают в этом участие.

Подпункты б), г) и е) п. 1 ст. 12 закона также закрепляют следующие права торговопромышленных палат:

1. Право направлять в органы государственной власти и органы местного самоуправления заключения по результатам экспертиз проектов законов и иных нормативных пра- вовых актов Российской Федерации, субъектов Российской Федерации, проектов муниципальных правовых актов;

2. Право участвовать в формировании и реализации государственной политики в области развития предпринимательства, в том числе путем участия в разработке и реализации государственных и муниципальных программ и проектов в области развития предпринимательства;

3. Право по предложению соответствующих органов государственной власти и органов местного самоуправления принимать участие в работе ведомственных, межведомственных и иных комиссий, экспертных советов и других органов и организаций, образуемых указанными органами.

Торгово-промышленные палаты имеют и другие права в соответствии со ст. 12 закона, однако данные права особо подчеркивают взаимодействие торгово-промышленных палат с органами государственной власти. В этой связи важно подчеркнуть, что другие общественные организации, ассоциации и союзы не имеют такого законодательно закрепленного порядка взаимодействия с государственными органами. В этой связи ТПП РФ имеет больший потенциал и возможности по представлению интересов своих членов в отношениях с государственной властью и обществом, чем другие ассоциации и союзы.

В ТПП РФ действует совет по интеллектуальной собственности. Его правовое положение определяется Положением о Совете Торговопромышленной палаты Российской Федерации по интеллектуальной собственности [5]. В соответствии с п. 2.1. положения совет создан с целью формирования, сохранения и развития интеллектуального потенциала отечественного предпринимательства на основе единой Концепции государственной политики в области охраны прав интеллектуальной собственности и вовлечения в хозяйственный оборот результатов интеллектуальной деятельности, а также с целью создания необходимых условий по обеспечению отечественной экономики высококвалифицированными специалистами в области управления интеллектуальной собственностью. Это определяет, что сфера деятельности совета распространяется на все вопросы интеллектуальной собственности, включая вопросы образования. Однако, как указано в п. 1.4. положения, 
решения, принимаемые Советом, носят рекомендательный характер и могут вноситься для рассмотрения на заседании Правления ТПП России. Данное ограничение является достаточно значительным, так как оно означает, что совет по интеллектуальной собственности не вправе от своего имени выполнять какие-либо функции ТПП РФ и взаимодействовать с государственными органами.

Однако, не стоит и принижать значение деятельности совета по интеллектуальной собственности. Так решения совета могут вноситься для рассмотрения на заседании Правления ТПП РФ, благодаря чему решения совета могут приобретать реальное действие. В соответствии со ст. 42 устава ТПП РФ [4] правление ТПП России является коллегиальным исполнительным органом Палаты, осуществляющим коллегиальное рассмотрение текущих вопросов деятельности ТПП России, не отнесенных Уставом ТПП России к исключительной компетенции Съезда, Совета и Президента ТПП России. Таким образом, при одобрении решений совета по интеллектуальной собственности правлением ТПП РФ, такие решения могут реализовываться в практической деятельности ТПП РФ, в том числе во взаимодействии ТПП РФ с государственными органами.

Но для того, чтобы в полной мере оценить значение деятельности совета ТПП РФ по интеллектуальной собственности, автор предлагает проанализировать основные результаты его деятельности за 2017 год. В связи с тем, что на момент подготовки данной статьи, в открытом доступе имеется только отчет о деятельности совета за 1-е полугодие 2017 года [7], предлагается оценить роль совета на основе данного документа и плана деятельности совета на 2017 год [6].

Так, в соответствии с планом деятельности совета ТПП РФ по интеллектуальной собственности в 2017 году планировалось осуществление 31 мероприятия, которые разделены по следующим направлениям деятельности совета:

1. Участие в разработке, экспертизе и сопровождении федеральных законов и нормативных актов;

2. Организация, проведение и участие в мероприятиях по проблемам отраслевого предпринимательства;

3. Взаимодействие с территориальными ТПП;

4. Выставочно-ярмарочная деятельность;

5. Взаимодействие с федеральными и ре- гиональными органами власти.

В рамках реализации данного плана деятельности в первом полугодии 2017 года члены совета вошли в состав рабочей группы по разработке новой редакции Соглашения о сотрудничестве в области охраны авторского права и смежных прав СНГ. Также советом инициирован ряд важных мероприятий.

В рамках информационно-методической поддержки инновационной деятельности в РФ, советом выпущена монография и подготовлены материалы для интервью Президента ТПП РФ С.Н. Катырина ТК «Россия24».

Особое внимание следует обратить на проведенные советом экспертизы нормативных правовых актов:

- проекта Федерального закона «О внесении изменения в статью 1252 Гражданского кодекса Российской Федерации», которым предусматривается возможность уменьшения судом размера завышенной в отдельных случаях компенсации, которая взыскивается с предпринимателя за нарушение прав на результаты интеллектуальной деятельности;

- подготовлен и направлен Председателю экспертного совета по развитию моногородов в Государственной Думе А.В. Балыбердину проект федерального закона «О внесении изменений в Федеральный закон «О статусе наукограда Российской Федерации» (далее - проект);

- проекта федерального закона № 126887-7 «О внесении изменений в Гражданский кодекс Российской Федерации», направленный на урегулирование деятельности организаций по управлению правами на коллективной основе.

Таким образом, исходя из анализа имеющихся за 2017 год отчетных материалов, деятельность совета ТПП РФ по интеллектуальной собственности, несмотря на тот факт, что его решения носят рекомендательный характер, имело важные практические результаты. Это проявлялось в рамках взаимодействия совета и ТПП РФ с органами государственной власти и участии в подготовке проектов нормативных правовых актов. Это позволяет сделать вывод о том, что деятельность ТПП РФ имеет важное значение для развития интеллектуальной собственности в России, хотя деятельность в сфере интеллектуальной собственности не является для ТПП РФ профильной. В связи с этим следует считать, что такая результативность может обуславливаться исключительно особым правовым статусом ТПП 
РФ, закрепленным на законодательном уровне.

Однако, по мнению автора, для более полного учета позиции авторов и правообладателей результатов интеллектуальной деятельности и средств индивидуализации в деятельности органов государственной власти необходимо законодательно закрепить право и других ассоциаций и союзов принимать участие в разработке проектов нормативных правовых актов и участвовать в формировании государственной политики в области интеллектуальной собственности.

\section{Библиографический список}

1. Конституция Российской Федерации от 12.12.1993 (ред. от 21.07.2014) // СПС КонсультантПлюс.

2. Гражданский кодекс Российской Федерации. Часть четвертая. Федеральный закон от 18.12.2006 № 230 -Ф3 (ред. от 03.07.2016) // СПС КонсультантПлюс.

3. О торгово-промышленных палатах в Российской Федерации. Закон от 07.07.1993 № 5340-1 (ред. от 01.09.2016) // СПС КонсультантПлюс.

4. Устав Торгово-промышленной палаты Российской Федерации // СПС КонсультантПлюс.

5. Положение о Совете Торгово-промышленной палаты Российской Федерации // http://tpprf.ru/ru/interaction/ committee/komint/about/

6. План работы совета ТПП РФ по интеллектуальной собственности на 2017 год // http://tpprf.ru/ru/interaction/ committee/komint/plans/?page=detail \&code=181097

7. Отчет о работе Совета ТПП РФ по интеллектуальной собственности в 1 полугодии 2017 года // http://tpprf. $\mathrm{ru} / \mathrm{ru} /$ interaction/committee/komint/reports/200365/

8. Барковская Л.Е. Виды организаций, создаваемых для осуществления и защиты интеллектуальных прав в России // Вопросы экономики и права. 2019. № 4. с. 29-33. 